\title{
LA AMBIDIESTRÍA EN ADULTOS
}

\section{Nixon Osorio Rojas*}

Lo ideal sería trabajar la ambidiestra antes de los cuatro (4) años, edad en que se define la lateralidad, pero como este trabajo no se realiza en la mayoria de los casos y se acostumbra a usar un lado más que el otro, adquiriendo habilidad y agilidad en el que se usa y perdiéndola en el otro.

Mi propuesta entonces, es que hagamos un esfuerzo por utilizar ambos lados e inculcar en nuestros alumnos esa actitud.

En nuestra edad creo que es posible, llegar a ser ambidiestros, el problema radica en la fuerza de voluntad, ya que este es un proceso que requiere bastante tiempo y paciencia en actividades ya aprendidas como escribir y es un poco má sencillo en las que hasta ahora se están aprendiendo.

Yo he practicado (entrenado) durante este semestre, en cada clase, mi escritura con la mano izquierda y este es mi resultado. Es difícil pero invito a la ambidiestría por 10 menos en lo escritura.

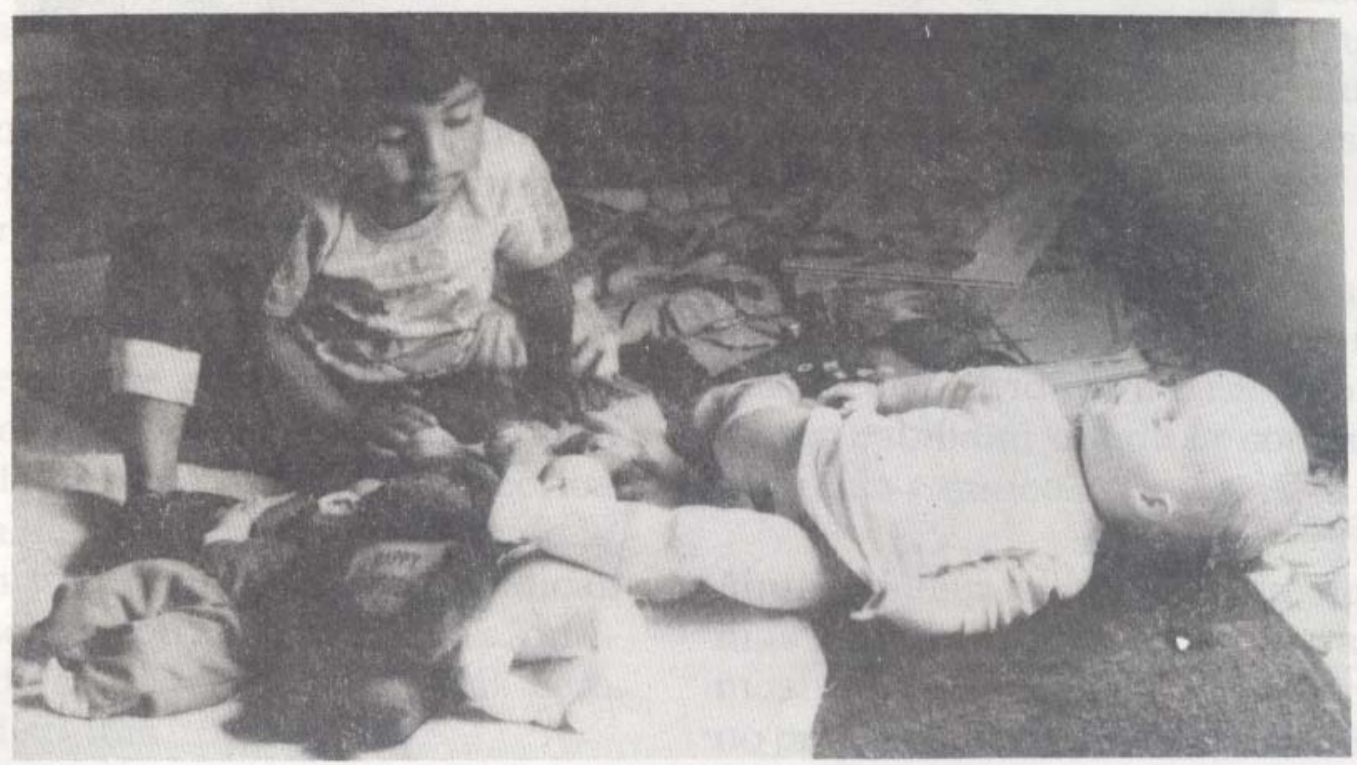

Estudiante Unıversidad Pedagogica Nacional

${ }^{*}$ Estudiante Universidad Pedagógica Nacional

Digitalizado por RED ACADEMICA 